\title{
HEALTH FOLLOW-UP OF CHILDREN IN POVERTY SITUATION: BETWEEN THE ROUTINE AND EVENTUALITY OF DAILY CARE
}

Débora Falleiros de Mello ${ }^{1}$

Regina Aparecida Garcia de Lima $^{1}$

Carmen Gracinda Silvan Scochi ${ }^{2}$

Mello DF, Lima RAG, Scochi CGS. Health follow-up of children in poverty situation: between the routine and eventuality of daily care. Rev Latino-am Enfermagem 2007 setembro-outubro; 15(número especial):820-7.

This study aimed to identify how child care is delivered to children under two in their daily routine. Based on a qualitative approach, the study addresses the care site in the child care, through non-structured interviews with mothers and professionals from two health units in peripheral areas of Ribeirão Preto, SP, Brazil. Results point aspects of how professionals view the mothers and their families, how the child's health, the routine and eventuality of care are followed. Adherence is important in the child's follow up, the longitudinality of care and, mainly, the concern with the mothers' and families' values. Child care in primary health care has a contingency character; it must deal with eventuality, uncertainty and events linked to experiences, integrating practical and technical knowledge.

DESCRIPTORS: child; infant care; follow-up, primary health care

\section{EL SEGUIMIENTO A LA SALUD DE NIÑOS EN SITUACIÓN DE POBREZA: ENTRE LA RUTINA Y LA EVENTUALIDAD DE CUIDADOS COTIDIANOS}

El objetivo de este estudio es identificar el modo como la atención en puericultura a niños menores de dos años de edad es realizada en el cotidiano. Basado en aproximación cualitativa, el estudio trata del sitio de la atención en puericultura en el cuidado en salud, utilizando entrevistas no estructuradas con madres y profesionales de dos unidades de salud de Ribeirão Preto-SP-Brasil. Los resultados apuntan aspectos sobre el modo como los profesionales ven a los sujetos, el modo como la salud del niño es acompañada, la rutina y la eventualidad de los cuidados. En el seguimiento del niño, es importante la adhesión al acompañamiento de la salud, la longitudinalidad de los cuidados y, sobre todo, la preocupación con valores de las madres y familias. El cuidado del niño en la atención primaria a la salud tiene carácter contingencial, debe lidiar con la eventualidad, incertidumbre y con acontecimientos vinculados a las experiencias, integrando saberes prácticos y saberes técnicos.

DESCRIPTORES: niño; cuidado del niño; estudios de seguimiento; atención primaria de salud

\section{A SAÚDE DE CRIANÇAS EM SITUAÇÃO DE POBREZA: ENTRE A ROTINA E A EVENTUALIDADE DE CUIDADOS COTIDIANOS}

Este estudo tem por objetivo identificar o modo como a assistência em puericultura destinada às crianças menores de dois anos de idade é realizada no cotidiano. Baseado em abordagem qualitativa, o estudo tematiza o lugar da assistência em puericultura no cuidado em saúde, utilizando entrevistas não estruturadas com mães e profissionais de duas unidades de saúde de áreas periféricas de Ribeirão Preto-SP-Brasil. Os resultados apontam aspectos do modo como os profissionais vêem as mães e famílias, o modo como a saúde da criança é acompanhada, a rotina e a eventualidade dos cuidados. No seguimento da criança é importante a adesão ao acompanhamento da saúde, a longitudinalidade dos cuidados e, sobretudo, a preocupação com valores das mães e famílias. 0 cuidado da criança na atenção primária à saúde tem um caráter contingencial, deve lidar com a eventualidade, incerteza e acontecimentos vinculados às experiências, integrando saberes práticos e saberes técnicos.

DESCRITORES: criança; cuidado do lactente; seguimentos; atenção primária à saúde

${ }^{1}$ Associate Professor, e-mail: defmello@eerp.usp.br, limare@eerp.usp.br; ${ }^{2}$ Full Professor, e-mail: cscochi@eerp.usp.br. University of São Paulo at Ribeirão Preto, College of Nursing, WHO Collaborating Center for Nursing Research Development 


\section{INTRODUCTION}

Although there have been advancements in child health in terms of reducing infant mortality and expanding health services' coverage, there are two important challenges to overcome: improve the quality of health interventions and reach the neediest children in Latin America and the Caribbean $^{(1)}$.

The programs and political guidelines directed at child health have mainly aimed to reduce infant mortality, which is considered an important indicator of social and economic development of a country or region. In global terms, current documents show that, per year, almost 11 million children under five years old die. Around 4 million of these deaths occur in the first month of life and a large part could be avoided if all children were already covered by existing interventions which, however, are not available for the majority of children in many countries. This highlights the importance of equity between as well as within countries $^{(1)}$.

Public entities have emphasized that these children's survival is not sufficient, but that it is also important to offer them conditions to have quality of life, allowing them to develop their potential and make use of the goods produced by society ${ }^{(2)}$.

In Brazil, child health is primarily structured around child care, focusing on growth control and child development, breastfeeding stimulation, guidance to child feeding, immunization, accident prevention and attention to prevalent childhood diseases ${ }^{(2-3)}$. These health practices constitute essential elements for good health conditions in childhood $^{(4)}$. In poverty situations, the intervention exerted by well planned integral child health care programs ${ }^{(5)}$ is extremely important.

In health care, it is relevant to address the encounter and interaction between subjects, families' particularities and cultural elements, the way we relate with others and organize care, seeking to contribute to the reconstruction of health practices.

This study aims to identify the way child care directed at children under two years old is performed in daily routine, based on reports of mothers and professionals at two units of the basic health network in Ribeirão Preto-SP-Brazil, in order to apprehend practical foundations and relationships with the care offered in health services.

\section{METHODOLOGY}

This study is focused on the qualitative approach, in the hermeneutic perspective ${ }^{(6)}$, studying the role of child care in child health care, considering care in an integrative perspective.

The research was developed in Ribeirão PretoSP-Brazil, in a family health unit (FHU) and a health basic unit (HBU), located in peripheral areas of the city. These units attend a predominantly young population that varies from 3,800 people (FHU) to 12,000 people (HBU). The area covered by the FHU includes a slum. The mothers who participated in the study were 18 to 29 years old and the number of children varied from one to eight.

Non-structured interviews were performed and recorded at the homes, at the $\mathrm{HBU}$ and at the FHU, between March and July, 2006. The guiding question used was "Tell me what it has been like to take care of your child" for the mothers and "Tell me what the care to children under two years old is like in your routine" to the health professionals.

A total of 17 mothers and 22 health professionals participated in the study (four nurses, four physicians, nine nursing aids and five community health agents), who were identified by codenames.

The research was approved by the Research Ethics Committee at the Ribeirão Preto College of Nursing - USP and at the Teaching Health Center of Ribeirão Preto Medical School - USP, following the standards and recommendations for research involving human beings.

In data analysis, after the interview transcription, readings and re-readings, organization and skimming ${ }^{(7)}$ were performed, organizing and structuring the parts and relating them for the identification of relevant ideas. The data were discussed in order to acquire a better comprehension as part of a whole, and this whole composed by these parts, thus constituting a coming and going between the part-whole-part that composes the meaning of these experiences ${ }^{(6)}$. The data were grouped around three themes: the way we see the subjects; the way we follow up the child's health; routine and eventuality in child's health.

\section{RESULTS AND DISCUSSION}

The way we see the subjects

We initially present some health professionals' reports with their view on the population 
from the area covered by the health units, especially on the mothers.

I've noticed that mothers are increasingly less interested in their children's care, so they bring the children as if they were a small parcel like, for you to see what to do, even the mothers who are constantly at home with their children. They don't know how to inform, they pick up the child from daycare and bring her here, it seems that they are outsourcing .their capacity of being a mother, they delegate everything about the child to the professional (Lola, physician HBU)

In our community, many mothers have to work, leave early, drop off the child in daycare, there are many viruses around there, which the child who has little resistance, which the child ends up catching and sometimes, you have to bring them, constantly, she [mother] cannot always bring her, have time, because the job is the most important for her. (Zeca, nursing aid $\mathrm{HBU})$

There are families that care less than others, also because of the culture itself. My micro area is the slum, there is the environment itself that is polluted, there are many houses that are precarious in terms of hygiene and others are, let's say, regular. Many mothers quit exclusive breastfeeding before six months despite their attendance to the unit, they think it is foolish so, at four months, even three months and a half, they start to offer other food to the child and sometimes, even the family's food. This is cultural, the values families have and learned or those they have lost also (Tina, community health agent FHU)

These professionals share their view regarding the mothers, who sometimes are uninterested in child care, sometimes with lost values, raising aspects regarding their postures in coming or not coming to the health service for the child's followup, related to the mother's work outside home, cultural issues characteristic of that population and to easy access to the health service. Some professionals refer to young mothers with their first child as being the more concerned and who adhere to child care. Others relate poverty to the difficulty of regularity in the child's follow-up in the health service.

The assiduity in the child's follow-up characterizes the careful and concerned mother, as the following reports show:

Here in the area, the population is really needy, lives in the slum, with bad socioeconomic conditions; this part of care has become a little deficient. I guess that there are two parts responsible for this, family and health service. Regarding the family, more because of some aspects or difficulties of the family in bringing the child for the follow-up, other mothers let the children in daycare the whole day to work and cannot leave work and end up not bringing the child. Usually, the child comes only when there is some problem. Especially those who already have children, the third or fourth child, she has some notion when the child is not well, if she is not, when she started to speak, when she started to walk, then they feel more secure than other mothers. I think that it is one of the factors of whether one is assiduous or not in child care, security on the mother's part (Dudu, physician $\mathrm{HBU})$

It is necessary to look at the child in her context. They raise these children like they were raised and these mothers, it seems to me, have little expectations, then they say "I don't need to worry if my kid will walk at the right time, if she is gaining weight at the right time, things are like this, life is like this". It is a way of dealing with things totally different from other mothers, even from us (Carol, nurse HSB)

Many families are really concerned with their children, get worried with the consultation itself, if it is scheduled and have to bring the child every month, to be weighed, measured, see if the child didn't lose weight, there are these concerned mothers, adhere very well, that mother who protects, it is that informed mother, but we also have those mothers who just take the child if she is sick, we have these two kinds of mothers (Néia, community health agent FHU)

The reports point to the clientele's sociocultural aspects, such as the context they live in and their life history, which lead to difficulties for the child's health follow-up, linked to family relationships and precarious living conditions.

There is a need to understand the children's growth and development process and their health and disease experiences as order and disorder simultaneously. There is a correlation between child health and certain socioeconomic indexes, but there are considerations on other relevant variables, because the child is linked to her mother and depends on her to survive. The broader area of general living conditions, such as feeding, housing, sanitation, access to health care and level of schooling, has to contemplate the mother's lifestyle, characterized as a series of behavioral aspects of sociocultural nature ${ }^{(8)}$.

Sharing the same values, beliefs and notions that people have about what is "good health" for the child implies sharing culture, so that this aspect is not unexplored or with a strong tendency to see and assume that the way we live is the best, a standard against which other must be judged ${ }^{(9)}$.

Child development must be understood in its historical, cultural and interpersonal context ${ }^{(9)}$, and it is important to consider the complexity of the interrelations between the subjects in development and the contexts they are inserted in. 
The way we follow up child health

The child follow-up at the two health units is highlighted in the reports, like in the following examples:

In the first six months the child is well followed, we look for the vaccine, the vaccine here is a well implemented thing, the child already comes, already has to come and take the BCG, we see the breasts, talk about the newborn screening, then she comes for the first consultation. In the first six months, she is more concerned with gaining weight, height, if the child is not nursing, if the milk is diminishing. From the age of six months on, that is the time when they start solid food, soup, don't know why, the mother herself starts to withdraw a little. In general, these are families with many children or that have to work (Déia, nurse $\mathrm{HBU}$ )

I think that, in general, it has evolved a lot, the parents are concerned, especially when the mothers are very young and sometimes, they don't know how to deal with certain situations in the first months, get anxious, exaggeratedly worried, which is natural, we've lived that already and have gone through all this. Many times they come more for psychological support, to have that confidence that everything is well, that things are really that way, that suddenly they get that defenseless little baby and they feel insecure, so I guess that this work is like this, not the care itself of realizing the baby is being physically mistreated, that she is not being cared with hygiene, sometimes there is that problem in the beginning, of the mother's adaptation to the baby, to clean, the crying bothers, all that process they are not used to and this makes them panic, scared sometimes, there is the older person who gives them misleading advice, and then there is that game and they get lost ( $L u$, nursing aid $\mathrm{HBU}$ )

I see with great satisfaction what we've managed to do here, children are born and we start to follow them very closely. From birth, we work with the mother, work breastfeeding, the vaccine issues, in the first year they are also calmer, you watch them closely, and the mother comes here many times. A very nice bond is created, it seems that since I am present at the moment they most need it, they always refer to me, there is a reference from the bond created, so on one side it gets distant, but on the other side some mothers remember how important the care was (Carol, nurse $\mathrm{HBU}$ )

I think we are successful in our work. We show in the visits the importance of child care, why not to lose any consultation, and they take it really serious, it is not rigid, we are even very flexible. Sometimes, they don't come and sometimes they have some problem at home and they can't come, not that they don't want to (Luli, community health agent HSF)

The beginning of the follow-up is highlighted as being early and close, they refer to breastfeeding as the mother's link with the health service and the professional support delivered in this situation. From the first year of life on, the follow-up is seen as a period in which the children have other needs and characteristics, they are not so dependent, making mothers detach a little from the health service. There are also reports about the success of the care, expressed by the adherence to child care.

In the case of child care, the systematic follow-up of the child's growth and development, involving basic actions, configures a technical success. Besides the adherence to child care, there is also a need to worry with the mothers and families' values and with the establishment of ties and co-responsibility between the subjects.

Mothers who regularly attend child care are appointed in the reports as more concerned mothers. They emphasize that they do not attend the health unit only when the child is sick, they look for breastfeeding orientation, how to educate their child, to know if she is gaining weight, feeding and development aspects. Other professionals report that mothers come to look for positive reinforcement regarding the care they perform at home, they want to gain confidence, to know that they are on the right course.

The mothers' reports also contain statements about the organization of the child health follow-up at the health units, in the perspective of health promotion and disease prevention, as shown by the reports below.

When I arrived home, the other day, they already came here, from the unit. Then, after 15 days, I went to the consultation, everything was ok. Then the follow-up went on, then every month, in the consultation to see if his health was ok, the growth, the weight. They taught me to prepare the food to give him, helped me in his growth follow-up and breastfeeding too, they taught me a lot of things. And we have to pay attention if he really wants to breastfeed or only suck, it is good because, if we have any doubts, they explain, because you are following the growth, for example, if he is six months and is sitting (Juju, 19 year old-mother FHU)

Here at the unit, every other two weeks, then for longer periods, now each three months, everything is ok, everything is right. I think it is good because you prevent, if the child has something we see it early, for example, if she has a cold, I already said it, if she doesn't get better, I take her because sometimes a little cold becomes a pneumonia. My kids were never hospitalized, never had pneumonia, bronchitis, and never had anything serious, so I guess it is because of it, because if you come regularly, they are always watching. (Dedé, 21 year old mother $\mathrm{HBU}$ ) 
The mothers report that the follow-up has a timetable of return visits, highlighting the following actions: monitor the child's growth and development; verify the weight; evaluate the breastfeeding and feeding scheme; prevent diseases; indicate the use of medications or verify the need to forward the child to other health services.

Some mothers emphasize the need for professional evaluation, both to validate their care and to learn more about it, like in the following examples.

I was anxious to complete the month and see how he was developing, to see if I was taking good care of him, if he was all right. When I got there, they started to see him, then they already said it is right mom your son is very well, he is super developing, is gaining weight. Wow, for me it was very rewarding to see them talking to me like that: you are taking very good care. There are careless mothers, don't care if the child is developing, or losing weight or not, there are mothers who think they don't need orientation: I myself will take care of my child in the way I know, the way I was raised, but it is not like that. So, everything is new, a new orientation and we are learning all the time (Duda, 21 year old -mother FHU)

You follow what is going on, how is the child's pace, if she is eating, if she is not. It is very good. It helps because every time you find out something, you learn more about the child, because it doesn't help if only the mother or the father says it is like that and that's it, the doctor knows what that is, what is going to happen, which is the development, if she is within normal standards, so it is important to come every month, taking the child to the follow-up at least once per month (Tetê, 23 years-mother $\mathrm{HBU}$ )

Thus, some mothers are interested in learning from the service, with the various consultations. The child's follow-up is permeated by going to the service and returning home. Coming back home is coming back to oneself, but the mother wants to go back to her home supported by words.

When the health professional provides information to the mother in the child's follow-up, (s)he is allowing for broad care. The mother who goes to the health service for the child's follow-up is seeking to strengthen her interaction with the professionals. Talking is an extremely important bond, as it collaborates to structure the potential space, to gradually construct the confidence, the safety, maternal identity and, consequently, strengthen the transitional phenomena that happen between mother and child.

The baby's gradual physical and emotional development is supported by the mother. For the baby's sense of security to develop, the mother needs to build, jointly with the child, the belief in something that is not only good, but also reliable and enduring. In that sense, the nurse's and physician's role gain emphasis in the construction of maternal security ${ }^{(10)}$.

The mothers also report situations in which they observed the child and behaviors adopted at home, like in the following examples.

If there is fever and the fever doesn't subside, for instance, I give medicine once and the fever comes back, I give a second time, if the fever comes back for the third time, or sometimes the medication effect is not over and the fever comes back stronger, I take her. It is always like this, strong fever, after about 38 I get worried. Now, if it is fever, like when she feels a little warmer, it is because of a cold, the teeth are growing too, then I don't get so bothered, because I know there are a lot of people who need it and I can't go there for nothing. (Tati, 22 year old-mother $\mathrm{HBU}$ )

She is a very smart child, very healthy. So, when I see she is cranky, weird, I know she has something, the child awakes crying, then she is cranky and doesn't let us do anything, so for us this is it, it is different, then I go and look at her carefully, sometimes is the teeth, or she has some pain, I give dipyrone and she gets better. When I see she doesn't get better, then I go to the unit, I go to see if it is something I can't take care of at home. At home, I give homemade syrup, then I get vick herb, mint, and some other herbs and put everything in the blender and then I put that on the stove, put some sugar and let it boil to a syrup, when it gets cold, I put it in a small bottle for my kids. So, when it does not get better, then I have to go to the doctor because I know that it is serious thing, a pneumonia, whooping cough, pneumonia gives fever, gives that dry cough, tiredness, so I consider it serious (Ciça, 26 year old-mother FHU)

The mothers tell what they observe and what they use in feeding, in the handling of respiratory symptoms, diarrhea, fever, skin problems, the use of medication, teas, among others. In this process of observing, of adopting some conducts and deciding when to take the child to the health service, you note their capacity of concern and uneasiness, which means responsibility on the mother's side.

There are mothers who demonstrate security and responsibility for the child, even in an economically less favored social situation, but she goes until a certain point and then she needs the other, the relation with the health service. She needs the other to perform care, which she normally does, but she realizes there is a limit for that. In this process, the mother experiments the limits of the insufficiencies in the relation with the child and, in some moments, this search for sufficiency will occur in the service. 
The decision to go to the health service calls attention because it tells about the responsibility in the child's health care, that is, the mother takes care seeking a sense of responsibility as taking it up for herself, of being accountable and in the search for interaction $^{(11)}$.

The demand for the health service is motivated by a search for something, what the individual feels is lacking, a need, which impedes him/ her to continue living according to the normality standard. It can be a physical pain, a suffering not yet physically identified or experienced or something experienced as a lack, as an information that calms down $^{(12)}$.

At the health services, in the professional observation of the mother-baby-family relation, if listening is available without judgment, the mother feels free to talk about her difficulties, including what she is not supposed to do, showing her contradictions, doubts, complaints and requests for help ${ }^{(13)}$.

The maternal concern is translated in the capacity to worry, and expression used to denominate responsibility, and this maternal capacity is considered the alternative that permits the child's and mother's development ${ }^{(10,14)}$

Routine and eventuality in child health

Routine and regularity, in contrast to eventuality in child care, are appointed in the reports, as stated by the health professionals below.

The mother who works, who rarely comes to the doctor, she comes when the boy is already sick. So, let's suppose she comes in the morning, because she is going to work in the afternoon, so, her life made her like this, she has to manage her problem and I think that I even accept that, you know? She is playing her role, has to defend herself and look for resources the way she can. And there are those of whom we know that they don't work and are at home. It seems they lost their interest, if the child is really sick, if she thinks it is going to be really serious, she comes, at any time, she wants to give a remedy, solve the problem right away, so she can go back to her life (Beta, nursing aid $\mathrm{HBU}$ ).

It doesn't matter how much you tell them, mothers here don't learn. The mother herself doesn't know how to prevent because they say like this: 'why am I going to need a crystal ball, my son will get sick and I have a crystal ball to schedule the consultation?' We schedule to prevent, that's what I think, health unit is prevention. There are mothers who come and say: 'my son has been vomiting for four days'. Wow, the child is vomiting for four days. Why didn't she bring the child on the first day of vomiting? I think it is complicated, mothers think only of the now. So, I don't know if it is lack of concern, if it is too many children, I don't know if the quantity of children, the house chores, if she works (Vivi, nursing aid $\mathrm{HBU}$ )

The professionals report on mothers who do not regularly attend the child care and appoint as associated factors the work outside home, the lack of time, the lack of interest in the child's follow-up, the expectation of fast care focused on the complaint, the little interest in health prevention, polarizing between preventing diseases and scheduling in the health services.

When reporting that the mothers lost their interest in the child's follow-up, there is an indication to rethink health care and that the spaces for the child's follow-up need more creativity, interaction and understanding of people's lives.

Protection of small children, for them to grow and develop, means assuring that the mothers will have an environment in which they can fully develop their maternal functions, full of promptness, joy and pleasure $^{(15)}$.

In the following statements, the professionals reinforce the mothers' health notion focused on curative care.

The impression is that they see health differently, but like, the fact of being sick does not mean you are not healthy. They don't see much this issue of health promotion, prevention, it is more the curative part actually. So, they don't do the followup correctly; don't worry about immunization, with breastfeeding, differently from those who do the follow-up, the well-done child care (Dudu, physician FHU)

These mothers do not have routine in their lives because of drugs use and the lifestyle, and they are children who demand too, and then dermatitis appears due to the lack of care. I let them come, I take that visit because she has dermatitis, because she has not taken good care, but then I do the child care. They appear and want fast care, because they have no patience. It is very complicated to deal with these mothers (Carol, nurse $F H U)$

I think it is normal for a mother to get worried when, for instance, a fever appears which, naturally they cannot explain, so a fever is always a great concern for them, so, they come after the early signs of fever and then I think it is part of the concern, there is a service nearby, and the child worries the parents, the family, mother so I think it is normal they come to the service. (Tina, community health agent FHU)

The professionals understand that the mothers see health with an emphasis on curative care 
and that regularity in child care is linked to social problems. Eventual care is taken to rethink the care offered to the population, including aspects of maternal concern, access to the health service, service availability and demand generated by the service itself.

It is important to rethink the bases of child care, the extent to which health surveillance and promotion are contemplating technical success, as well as the mothers' and family's values, beliefs, attitudes, decisions and projects.

Building educative strategies that permit investing in possibilities of transformation of living conditions, in which beliefs, habits and behaviors gain sense, demands learning, understanding and dialogue with the multiplicity of aspects that affect the beliefs, habits and behaviors of the individuals and groups we interact with ${ }^{(16)}$.

Mothers possess a global knowledge, based on common sense and linked to their material conditions of existence. However, at the same time, they value scientific knowledge and attempt to conduct their children's education according to child care norms, which they have often already incorporated ${ }^{(8)}$.

Health and nursing practices in children's follow-up in the family context are a broad and continuous process which, beyond technical references, imply promotional, preventive, therapeutic measures and interactions with the child, family, community, health services and other social sectors $^{(17-18)}$.

\section{REFERENCES}

1. Victora CG, Barros FC. Global child survival initiatives and their relevance to the Latin América and Caribbean Region. Rev Panam Salud Publica 2005; 18(3):197-205.

2. Ministério da Saúde (BR). Agenda de compromissos para a saúde integral da criança e redução da mortalidade infantil. Brasília (DF): Ministério da Saúde/Secretaria de Políticas de Saúde; 2004

3. Ricco RG, Del Ciampo LA, Almeida CAN. Puericultura princípios e práticas: atenção integral à saúde da criança. São Paulo (SP): Editora Atheneu; 2000.

4. World Health Organization. Care in normal birth: a pratical guide. Geneva: WHO/Maternal and Newborn Health/Safe Motherhood; 1996.

5. Monteiro CA. A dimensão da pobreza, da desnutrição e da fome no Brasil. Rev Estudos Avançados USP 2003; 17(48):7-20.

6. Ayres JRCM. Hermenêutica e humanização das práticas de saúde. Ciênci e Saúde Coletiva 2005; 10(3):549-60.

7. Minayo MCS. O desafio do conhecimento: pesquisa qualitativa em saúde. São Paulo (SP): Hucitec; 2000.

\section{FINAL CONSIDERATIONS}

Reflections on child care are important to review its focus, commonly based on an ideal model of child growth and development.

We do not deal only with a linear follow-up in child health. There are obstacles, diseases, values and several experiences of child care. To grant more sense to child follow-up practices, it is important to organize the care, reviewing the technically established frequency and periods, negotiating with the mothers, promoting more creative encounters, taking care of the singularity of each child-mother pair and of each family and understanding the range of the health-disease and care process in concrete realities.

Thinking how health professionals are taking care and interacting with the mothers from a certain community implies rethinking the relations, actions and commitments. In child follow-up, it is important to reach adherence to child care, care longitudinality and, especially, the concern with the mothers' and family's values. There are decisions involved in this process in which actions can and must be taken, leading to a reconstruction of knowledge and practices for the innovation of care production in contextualized realities.

Child care at primary level has a contingent character; it must deal with eventuality, uncertainty and events linked to experiences, integrating practical and technical knowledge.

8. Dytz JLG, Rocha SMM. O modo de vida da mãe e a saúde infantil. Rev Bras Enfermagem 2002; 55(2):151-6.

9. Tudge J. Estudando a criança e a família em seu contexto: para uma abordagem cultural da tolerância. In: Biasoli-Alves ZMM, Fishmann R, organizadoras. Crianças e adolescentes: construindo uma cultura da tolerância. São Paulo (SP): Edusp; 2001. p.65-77. 10. Winnicott DW. A família e o desenvolvimento individual. São Paulo (SP): Martins Fontes; 2005.

11. Ayres JRCM. Cuidado e humanização das práticas de saúde. In: Deslandes S, organizadora. Humanização dos cuidados em saúde: conceitos, dilemas e práticas. Rio de Janeiro (RJ): Fiocruz; 2006. p.49-83.

12. Schraiber LB, Mendes-Gonçalves RB. Necessidades de saúde e atenção primária. In: Schraiber LB, Nemes MIB, Mendes-Gonçalves RB, organizadores. Saúde do adulto: programas e ações na unidade básica. São Paulo (SP): Hucitec; 1996. p.29-47.

13. Franceschini TRC. Observação da relação mãe-bebêfamília como ferramenta para o aprendizado da integralidade. [dissertação]. Ribeirão Preto (SP): Escola de Enfermagem de Ribeirão Preto/USP; 2005. 
14. Abadi S. Transições: o modelo terapêutico de D.W. Winnicott. São Paulo (SP): Casa do Psicólogo; 1998.

15. Oliveira H, Minayo MCS. Complexidade e mortalidade infantil. In: Minayo MCS, Deslandes SF, organizadoras. Caminhos do pensamento: epistemologia e método. Rio de Janeiro (RJ): Fiocruz; 2002. p.49-82.

16. Meyer DE, Mello DF, Valadão MM, Ayres JRCM. Você aprende. A gente ensina? Interrogando relações entre educação e saúde desde a perspectiva da vulnerabilidade. Cad Saúde Pública 2006; 22(6):1335-42.

17. Mello DF, Rocha SMM, Scochi CGS, Lima RAG. Brazilian mothers' experiences of home care for their low birth weight infants. Neonatal Network 2002; 21(1):30-4.

18. Figueiredo GLA, Mello DF. A prática de enfermagem na atenção à saúde da criança em unidade básica de saúde. Rev Latino-am Enfermagem 2003 julho-agosto; 11(4):544-51. 